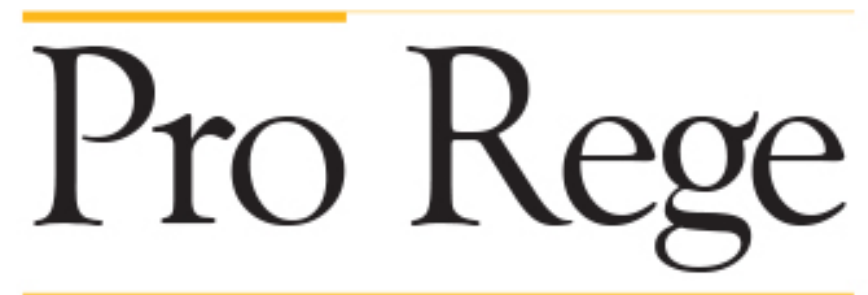

Volume 33 | Number 1

September 2004

\title{
Historical Background to Conflicts over Religion in Public Schools
}

Charles L. Glenn

Follow this and additional works at: https://digitalcollections.dordt.edu/pro_rege

Part of the Christianity Commons

\section{Recommended Citation}

Glenn, Charles L. (2004) "Historical Background to Conflicts over Religion

in Public Schools," Pro Rege: Vol. 33: No. 1, 1 - 19.

Available at: https://digitalcollections.dordt.edu/pro_rege/vol33/iss1/1

This Feature Article is brought to you for free and open access by the University Publications at Dordt Digital Collections. It has been accepted for inclusion in Pro Rege by an authorized administrator of Dordt Digital Collections. For more information, please contact ingrid.mulder@dordt.edu. 


\section{Historical Background to Conflicts over Religion in Public Schools}

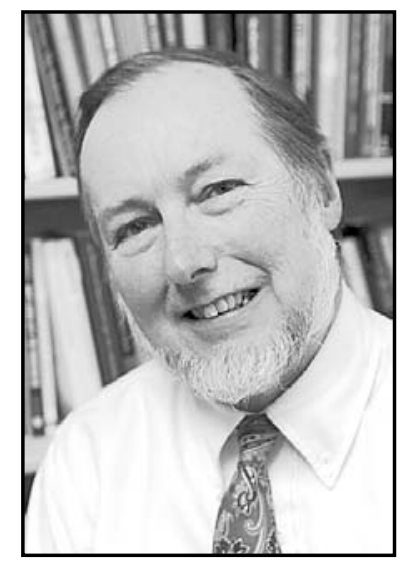

by Charles L. Glenn

$\mathbf{C}$ onflict over how to accommodate religious convictions in public schools has become a familiar theme in the United States. While American public schools - at least the good ones, the ones that are not wishy-washy-stand for a way of understanding the goals of education and thus of

Dr. Paul Glenn, Fellow of The University Professors and Professor of Education, Administration, Training, and Policy Studies at Boston University, School of Education, Boston, Massachusetts, has authored the following works: The Myth of the Common School; Educating Immigrant Children: Schools and Language Minorities in Twelve Nations; Educational Freedom in Eastern Europe; The Ambiguous Embrace: Government and Faith-based Schools and Social Agencies; and (with Jan De Groof) Finding the Right Balance: Freedom and Accountability in Education. Dr. Glenn has also authored book chapters (more than 60 chapters in collections and published articles) and published more than 120 articles and reviews.

a good and flourishing human life, they are not free to base that understanding on explicitly religious themes. This lack of freedom is by no means self-evident. For Horace Mann, often considered "the Father of American public education," it was beyond question that the school day should include reading from the Bible-passages carefully selected to reflect his optimistic and moralistic Unitarianism, and intended to be universally acceptable. He and his allies were promoting the common public school, he wrote in 1846, in order "to elevate mankind into the upper and purer regions of civilization, Christianity, and the worship of the true God" (Glenn, Common School 172-175). His religious critics, both Protestant and Catholic, charged that he was advocating an understanding of religion which had little to do with its real power or with what they believed.

The First Amendment to the Constitution has been interpreted to forbid any level of government-including local public school systemsfrom engaging in or directly supporting religious practices. However, even if that interpretation changed, it's not at all clear that people for whom religious beliefs are very important would want a government agency deciding how those beliefs would be interpreted and taught. Nor would we want children whose beliefs differ from those of the school forced to choose between violating their consciences and being singled out by asking to be excused. Nor would those for whom prayer is important want to see it trivialized as a way to quiet down a class, as has been suggested by some advocates of "school prayer."

In short, the American government is required, for very good reasons, to be neutral between various religious beliefs, and also to be neutral between belief and non-belief. Schools operated 
directly by government must act in ways consistent with that requirement, and so must each of their teachers. They must not seek to promote any particular religious belief, nor may they in any way promote secularism (a way of understanding the world that explicitly rejects any idea of divine purpose or meaning) in preference to religion.

Schools operated by government, then, should not behave like a church or other religious institution; they should not ask their students to engage in religious practices. In a recent case, a federal judge ruled that a New York State school district had violated the rights of Christian families by having their children cut out images of a Hindu god and build an altar and join in New Age prayers for an Earth Day ritual. "While reading the [Hindu god's] story can be part of a neutral secular curriculum," the judge pointed out, he could not find "any educational justification for telling young impressionable students to construct images of a known religious god." Building the altar, he found, was "truly bizarre" in a public school (Zielbauer, Paul. "Judge Rules School District Erred on Religion in Classroom." New York Times 22 May 1999).

This particular event and response does not mean that teachers should not mention religion, should not present in accurate ways the role of religious belief and religious institutions in American history and society, and should avoid mentioning religious motivations in discussions of how we should make decisions about sexuality, social justice, and other issues. The Supreme Court has noted that it would be an inadequate education that did not give students an understanding of the role that religion has played in history and plays in our society. After all, as Justice Clark wrote for the majority in an important case, one's education is not complete without a study of comparative religion or the history of religion and its relationship to the advancement of civilization. It certainly may be said that the Bible is worthy of study for its literary and historic qualities. Nothing we have said here indicates that such study of the Bible or of religion, when presented objectively as part of a secular program of education, may not be effected consistently with the First Amendment. (Abington School District v. Schempp 374 U.S. 203, 1963).
One of the most liberal justices pointed out, in the same case,

[t]he holding of the Court today plainly does not foreclose teaching about the Holy Scriptures or about the differences between religious sects in classes in literature or history. Indeed, it would be impossible to teach meaningfully many subjects in the social sciences or the humanities without some mention of religion. To what extent, and at what points in the curriculum, religious materials should be cited are matters which the courts ought to entrust very largely to the experienced officials who superintend our Nation's public schools. They are experts in such matters, and we are not. [Justice Brennan, concurring]

Unfortunately, most public schools have been guilty of what can only be called a cowardly avoidance of this aspect of life. For example, one study found that most textbooks never mentioned that Martin Luther King, Jr., was a minister, or that religion played a fundamental role in the Freedom Movement of the 1960s. There was no mention, in discussions of current American society, of evangelist Billy Graham, who has consistently been one of the most popular Americans for the last thirty years, or of the fact that more Americans attend religious services each week than attend professional sports in a year!

It is entirely possible to teach about religion as a social reality, and about the scriptures of different religious groups, without seeking to convert anyone or to favor any particular faith. That kind of teaching has been done in public schools, and good curriculum and materials exist to support teachers who seek to do so in an objective way. But few do, nor is there room for teaching about religion in the curriculum of most schools. Until curriculum standards and textbooks changewhich is beginning to happen-we cannot expect much better.

Many parents believe that the public schools are hostile to religion. I think those parents are wrong- "willfully neglectful" would be more accurate-but I can understand their reaction. And this reaction has contributed to undermining support for the public schools, and to surrounding them with conflict. Many leading educators, in turn, do not hesitate to describe Christian organizations as "the enemy." I think that such educators are wrong, too, but again I can understand 
why they find it so difficult to hear what their critics are saying.

In some other Western democracies, like the United Kingdom, Italy, and Germany, religious instruction is provided as part of the regular public-school program, with students or their parents allowed some choice among Protestant, Catholic, and other alternatives. In English schools, each school day is supposed to include a daily act of worship of a predominantly Christian character, even in schools where most of the children are Muslim or Hindu.

Germans were divided, a few years ago, over whether schools in Bavaria should be requiredwhen parents objected-to remove the crucifixes, which have traditionally hung in each classroom; the outcome required a ruling by the national Constitutional Court. More recently, the same court has considered whether Muslim teachers in public schools have a right to wear the hijab or scarf covering their hair, and this issue will have to be addressed by legislators. While the issue seems to have been resolved in Germany, litigation over a crucifix in a public-school classroom stirred passions in Italy as the 2003-2004 school year started. Devout Catholics were not necessarily those most opposed to the removal of crucifixes at the demand of a parent who had converted to Islam; for some, the removal of crucifixes was a convenient symbol of unwelcome societal changes resulting from immigration and from a rapidly-evolving culture.

Whether to include the theory of evolution in state-mandated examinations caused a political crisis in the Netherlands in mid-1995: a group of conservative Protestant Reformatorische schools objected, and a characteristically Dutch compromise was reached. Compromise is rarely the outcome of such controversies in the United States. Americans go to court (as in the current Pledge of Allegiance case) and winner takes all.

In France, the determination of hundreds of Muslim girls to wear the hijab or scarf covering their hair in school has divided opinions on the Left and Right alike, and seems no closer to resolution after fourteen years of controversy. Schools in the U.S., according to the Department of Education's clarification in 1998, "may not single out religious attire in general, or attire of a particular religion, for prohibition or regulation."
Responding to the French proposal of a law to forbid the wearing of religious symbols in schools, the Bush administration's top official on issues of religious freedom stated that "a fundamental principle of religious freedom that we work for in many countries of the world, including on this very issue of head scarves, is that all persons would be able to practice their religion and their beliefs peacefully, without government interference, as long as they are doing so without provocation and intimidation of others in society."

Considered comparatively, several questions suggest themselves to an American observer. Why, for example, is religion such a presence in public schools in Germany and England, while it is banned completely from public schools in the United States, a country where religious practice has remained much stronger? Why, given the strict secularity of public schools in the United States, are Muslim girls allowed to wear the hijab while in France, with a similar "republican" tradition of schooling, is it a continuing source of controversy? Why have most Western democracies organized their systems of public education on a pluralistic basis-the Netherlands, Belgium, Northern Ireland, Australia, much of Canadawhile in others, such as the United States and Italy, a system of government monopoly of the provision of public education is only beginning to change?

To begin to answer these and other questions, we must look to the period in the nineteenth century when universal popular education developed in several countries, and also to the more recent period when each was forced to come to terms with a growing diversity of and conflict over ways of understanding the world and the goals of education.

\section{France}

If the Dutch have leaned over backwards to protect the rights of schools of distinctive character corresponding to the views of minority groups, in France the prevailing assumption is that social unity depends upon a common experience of schooling. The desire of some Muslim girls (voluntary in some cases, coerced in others, it seems) to cover their hair in class with a scarf or hijab has been widely interpreted as an imper- 
missible intrusion of religion and ethnicity into schools. The Jacobin model of aggressively secular public education seeks to confine real human differences-including religious convictions-to the private sphere. This typically French "secular fundamentalism" fails to take into account the communities and beliefs by which people (not just Muslim immigrants) structure their lives.

"Secularism has demonstrated its intolerance," said a young Muslim high school teacher in the wake of expulsions of hijab-wearing girls from a school in Lille; the time had come to demand public funding for separate Muslim schools, as in the Netherlands. The Ministry of Education has in fact already received applications from such schools, and it seems only a matter of time before some receive contracts and public funding.

The French government policy of directing schools to exclude girls who insist upon covering their hair with an hijab seems likely, some observers contend, to have an opposite effect than intended: rather than promoting the integration and acculturation of immigrant pupils, it marginalizes them further by accentuating how they are different. The hijab has become the preeminent symbol of Muslim rejection of the values of French society-and of modernity in generalprecisely because it has been banned from schools. The president of the Conference of Catholic Bishops has predicted that the proposed complete ban will have the effect of increasing separatism (Le Point 14 November 2003).

Obsessive anticlericalism was a major theme of French political life throughout the nineteenth century and much of the twentieth, often bringing together activists who could agree on no other issue than their opposition to the influence of the Catholic Church. Popular schooling was the sphere where this concern was expressed most strongly, and the strong growth of Catholic teaching congregations around 1850 caused grave concern in these circles. Anticlericals assumed that the education received in Catholic schools would make their pupils unfit to be citizens. In a celebrated formulation in 1822, General Foy lamented that "they will have received in these establishments, which are not national, an instruction which is not national, and thus these establishments will have the effect of dividing France into two youths (deux jeunesses)" (qtd. in Rémond
114). A generation later, influential Catholic layman Charles Montalembert described "two armies face to face, each of about thirty to forty thousand men: the army of teachers and the army of priests .... The demoralizing and anarchical army of teachers must be countered by the army of priests" (Ponteil 230-31, 235).

It is, in fact, during this period that the term laïque (secular) began to be applied to a program of opposition to clerical influence on social institutions. "Anticlericalism," Rémond points out, "is not religious indifference, quite the contrary"; it is more a counter-religion than a non-religion. The term itself began to be used around 1852 (Rémond 46, 0). Thus, Arsène Meunier published a book entitled "struggle of the clerical principle and the secular principle in education" (1861), insisting that "the State is secular, and in consequence the instruction given in its name must be secular, and if this word doesn't seem clear, we will say that it signifies for us that public education, without being irreligious, must forget all positive religion" (qtd. in Barbier, 7n). The word laïcité (secularity) has been traced to 1871 , in connection with a debate about schools.

Not that this laïc position was neutral with respect to the worldview to be promoted in public schools. The Republicans who shaped French institutions in the last quarter of the nineteenth century "had all borrowed from [Auguste] Comte the idea that a spiritual power was necessary to establish a republic ... and all ended by joining the Freemasons . . . and all wanted to make the School and the University this new Church" (Nicolet 156-57): "For Comte as for all his disciples, instruction and education-for the two are inseparable-were at the very base of the regeneration of humanity." Their educational program forbade "all illusory questioning about prime causes or final ends, which absolutely excluded all transcendence" (Nicolet 28).

The first decades of the Third Republic were the high point of Masonic influence on public life and on education (as it was in contemporary Italy), and of Catholic opposition to this influence; Pope Leo XIII condemned the Masons, in 1884, as the "party of Satan." While French Masons had been vaguely deist earlier in the century, in 1876 the Grand Orient suppressed in their constitution all references to God or the existence 
of the soul (Rebérioux 43). It was not without significance that "throughout the Third Republic the Ministry of Public Instruction was traditionally occupied by Masons," and in 1899, 150 members of the Chambre de Députés were Masons (Ozouf and Ozouf 219; Visse 149). It is no exaggeration to say that "Masonry constituted the cadres and the school of the Republican party" in the Third Republic (Chevallier 550).

This masonic involvement led inescapably to conflict with the Catholic Church: "One does not understand the ... republicans of the $19^{\text {th }}$ century if one does not realize that the anti-clerical struggle seemed to their eyes, as the result of a century of unhappy experiences, as the inevitable precondition, although never definitively achieved, of all future progress: literally, as the motor of history." It was a matter of achieving the moral unity of the nation, more important even than its territorial or legal unity. All intermediate associations between the nation and the individualapart from tightly controlled local administration-were seen as an unacceptable threat to this unity. Even more challenging to the authority of the Republic was any form of transcendence that suggested a higher source of authority (Nicolet 273, 447, 484).

A law passed in March 1882 made elementary schooling obligatory and secular, specifically excluding from the curriculum the teaching of "obligations toward God." The government sometimes showed a degree of flexibility in communities where parents were strongly insistent upon maintaining elements of the religious character of local schools. A ministerial circular gave departmental officials "complete latitude to make allowances in this respect for the wishes of the population," and some public schools continued to display the crucifix on classroom walls as late as 1906 (Curtis 142). Nevertheless, "far from establishing unity, the insistence on lay education and the elimination of God from the civic [education] manuals, divided the country profoundly, and exacerbated the clash of Church and republic" (Zeldin 262).

In 1909, some secular activists began to advocate a state monopoly of schooling (Mona Ozouf 231). Opponents of religion were found not only in the masonic lodges but also in more than a thousand organizations of "freethinkers," "pursu- ing ardently the completion of the work of the French Revolution and intervening in all sectors of the life of the country to secularize the State and the society, to "ensure the complete laïcité of the French spirit." Educational freedom, they insisted, was merely a sophism as long as there was a church seeking to distort the souls of children: "There can be no freedom in the presence of clericalism" (Lalouette 292).

In fact, in the political struggles over education that troubled France for several decades-indeed, that have never really ceased-both sides invoked "freedom" as their guiding principle: "It was a conflict of two freedoms. Two divergent conceptions of liberty were in confrontation: one defended the right of [members of religious orders] to teach freely; the other sought to liberate the country from the grip of [teaching] congregations which surreptitiously educated youth in the 'hatred' of the Republic" (Baubérot 47).

Paradoxically, as Charles Renouvier and other moderate anticlericals had warned (Blais 323), measures to drive religion out of the public schools actually had the effect of strengthening alternative Catholic education. Abolition of public funding for the salaries of bishops and priests, which had prevented effective resistance to the measures secularizing public schools in the 1880s, freed them to make Catholic schools a priority. In areas of strong religious practice, many new schools were established (Déloye 233).

Supporters of subsidies for private schools were able, under the Fifth Republic, to achieve passage of the Loi Debré, adopted December 31, 1959. As Prime Minister Michel Debré said in parliamentary debates, the private sector, with $1,797,000$ pupils, "brings to the education of French youth a cooperation which it would be unjust to fail to recognize" (Visse 62). This law, still in effect, asserts that "the State proclaims and respects educational freedom," and establishes a system under which non-state schools enter into contracts with the State for the provision of educational services, while maintaining some measure of autonomy (see discussion in Glenn and De Groof Vol. I, 252-66).

In 1996-97, there were almost 25,000 pupils attending unsubsidized private secondary schools, in contrast with the more than 1.1 million in subsidized secondary schools under con- 
tract with the state (Durand-Prinborgne 67). Almost all non-public schools are Catholic: 96 percent of the pupils in non-public elementary schools and 86.4 percent of those in non-public secondary schools in 1990-91; altogether, Catholic schools serve nearly two million pupils. The real distinctiveness of these Catholic schools is sometimes called into question, since those that receive public funding are required to conform themselves in many respects to the ever-changing model of public schools. In a highly secularized society, it is to be expected that the religious distinctiveness of Catholic schools is sometimes difficult to detect.

How does the French treatment of the religious dimension (whether explicit or implicit) of education compare with that in the United States? It has been suggested that the pattern of accommodation of religion in American society consists of a triangular pattern of religious freedom, disestablishment of churches, and pluralism, while the corresponding French triangle is religious freedom, an implicit state church, and civil unity (Baubérot 290). In effect, according to this analysis, France never went through a "disestablishment"; there was instead a replacement of the Catholic Church by the secular "Church of the Republic," with its well-articulated worldview, a mixture of Comtean positivism, Kantian ethics, and intense nationalism in reaction to the humiliation of 1870 :

The new God of Comte, the religion without dogmas of Buisson, Freemasonry or the Socialism of Jaurès are all responses to this need and this challenge. But the France of the Ancien Régime had known for too long and too deeply the penetration of the Church and the State for the Republic to be able to accommodate itself to the simple equality of religions or the simple freedom of conscience. Every religion, divine or secular, takes among us a dogmatic form and seeks naturally to organize itself as a Church and to penetrate the State. (Nicolet 499)

As a result of this switch of establishments rather than disestablishment, and (as Quinet and others argued in the 1850s) of the defeat of the Reformation in France in the sixteenth century, religious pluralism has never flourished in France, as has been evident in the current difficulties about how to come to terms with Islam, for which the symbolical focal point has been the wearing, by schoolgirls, of the scarf or hijab in class (see Gaspard and Khosrokhavar; Glenn, "Limits of Tolerance").

\section{Germany}

Governments of the various states that came together in 1870 to form modern Germany had used the state-supported Protestant and Catholic churches to provide oversight over local schools that were not, however, church-run. It was made very clear that the role of local clergy was as agents of the government, and government did not hesitate to remove them from supervising or providing religious instruction in schools when there was any reason to doubt their full loyalty to the regime, as occurred in Prussia's Polish provinces and in Alsace-Lorraine during the Kulturkampf.

Despite these occasional tensions, however, almost all elementary schools retained a confessional character: they were Protestant or Catholic or (in a few cases) Jewish public schools, despite frequent demands from advanced elements of the teaching profession that the schools be made religiously-neutral or "interconfessional" with separate religious instruction. For those concerned about the role of religion in education, the interconfessional school threatened to marginalize it into "merely one subject in the curriculum [which] would no longer penetrate and inspire the entire instruction." "The fight for the interconfessional school, which raged a generation ago," Minister of Education Studt wrote in 1903, "no longer stands in the foreground of the activities and interests" of the parties at the dominant center of the political spectrum. "People have recognized that the interconfessional school carries with it disadvantages insofar as it is apt to impair not only religious and moral education but also the cultivation of patriotism" (qtd. in Lamberti 213).

Hopes that interconfessional schools would have a unifying influence on a religiously divided society were disappointed; in cities where they were imposed by a liberal elite, "the results were political strife rather than social integration and mutual respect between the religious groups" (Lamberti 214). In another sense, of course, they did promote Catholic and Protestant cooperation 
in opposition to secular liberalism.

The effect of accommodation of religion within the Volksschule was to maintain state monopoly of popular schooling, since accommodation made it unnecessary for Catholics and orthodox Protestants to create their own schools, as occurred in the Netherlands: "Teaching religion as a required subject in the public schools guaranteed that the instruction remained under the state's oversight and served the state's interests" (Lamberti 217).

Although opposed to denominational schooling, German liberals were not calling for the exclusion of the teaching of religion in the schools, since including it "guaranteed that the instruction would be given in the state's interests and under the state's supervision," and the alternative seemed to be the danger that a system of parochial schools would be created. Liberals warned that if the State "permits private schools freely in order to satisfy special confessional interests, then it is only serving the ambitions of the clergy to dominate [education], as the example of Belgium proves" (Lamberti 63). Similarly, government officials were concerned that removal of religion from the Volksschule would lead to establishment of private church schools not under direct state control; they "doubted that religiously neutral communal schools would compete successfully with Catholic private schools and thought that a large part of popular education would soon be removed from the control of the state. The surest way to preserve the state's monopoly of education was to have the public schools serve the purposes of the church as well as the state" (Lamberti 216).

In a continuation of the strategy adopted in the mid-nineteenth century, government continues to offer denominational religious instruction in public schools as a way of reducing the demand for private confessional schools. Such instruction enjoys a constitutional guarantee, and "must remain as a free-standing subject in the public school" (Avenarius and Heckel 69). Public schools must therefore provide space, materials, and teachers, as well as any additional costs for religious instruction, and the grades that pupils receive in this subject can count in the same way as grades in other subjects, even for promotion (Thiel 106). In addition to such external guaran- tees, it must be said, there have been notable efforts to make religious instruction "more correct, believable, methodologically modern, and humanly helpful" (Reble 202, 377).

Schools in Germany today are not ideologically neutral; they have a responsibility to develop in their pupils those dispositions considered necessary to maintain society and the political order. How to define these, and how to implement value-laden programs without conflicting with individual freedoms, is an on-going problem, as in other countries.

In Bavaria, the Land with the most conservative and Catholic influence, an initial effort was made with American support to implement interdenominational Simultanschulen in place of restoring confessional schools, but the attempt encountered such determined opposition that it was abandoned, and the Bavarian Constitution guaranteed a right to confessional education; in 1988 the Bavarian Constitutional Court concluded that the specification of the 1946 state Constitution, that "reverence for God" was among the highest objectives of Bavarian schools, was consistent with other provisions protecting individual rights (Tent 112, 127, 139; Spotts 86; Waterkamp 262). However, this reverence must not be understood in the sense of establishing a state religion with a particular way of understanding the divine (Thiel 125-31).

Displaying crucifixes in classrooms was simply a manifestation of this accommodation of religion within, rather than alongside, German public schools. Symbolic expressions of the Christian faith are ubiquitous in Western nations, nor would one have to look far, in most European cities, to find signs of an Islamic presence as well. No one is sheltered from such sights, any more than from the images of violence and sexuality which children pass on their way to school. The German Constitutional Court decided, however, that public elementary schools represented a different situation: "Together with compulsory attendance, crosses in classrooms have the effect that during instruction pupils are confronted with this symbol, on behalf of the state and without the possibility of avoidance, and are forced to learn under the cross."

The court's majority rejected the contention of three of its members that the cross was merely a 
reminder of the influence of Christianity upon Western culture. "Plainly a symbol of belief," while it doesn't compel the children to identify with Christianity, the cross "sets out the contents of the faith symbolized by it as exemplary and worthy of adherence." Some observers noted that Christians would have had more reason to protest if the court had accepted the argument that a crucifix was no more than "a sentimental wall decoration"!

This ruling did not ban crucifixes from classrooms, but it stated that the state could not require them without regard to the objections of parents. Many of those reacting to the decision, Socialists as well as Christian Democrats, drew the lesson that it should be left up to each school-not to the state-to determine what religious symbols to display; several Catholic and Protestant church leaders suggested that Muslim, Jewish and other symbols would be appropriate alongside the cross, depending upon the pupils in the school, and "would contribute more to mutual understanding and tolerance than would a naked wall."

\section{The Netherlands}

The Dutch have avoided the tyranny of the majority in education by providing public funding for a wide diversity of schools. Any group that can meet state standards and convince enough parents to enroll their children is able to operate a tuition-free school; in fact, only 30 percent of pupils attend government-operated schools. This approach has encouraged responsible experimentation and minimized conflict over education. In August of 1995, however, there was a brief but intense flare-up over the right to differ from the prevailing orthodoxy about evolution.

The government had decided several years before that nationwide examinations in biology would not include Darwin's theory; schools would be required to teach about it and assess student knowledge by their own tests. This decision was based upon advice from the board responsible for interpreting constitutional guarantees of educational freedom. Evolution, it concluded, was a sensitive matter (comparable to abortion and euthanasia) that each school should be allowed to handle in its own way, to protect its distinctive identity.

Members of the Left-of-Center coalition then in power sought to require that the theory of evolution be required on nationwide examinations. Those opposed argued that the question was whether there was a divine purpose for human life or not, and that public policy should respect the convictions of that part of the population who chose schools where this purpose was considered central. Supporters of educational freedom rallied, and the effort to include evolution on national examinations failed. Once again, the pluralistic approach to national life advocated by Abraham Kuyper was vindicated.

A true system of primary schooling emerged in the Netherlands in the first years of the nineteenth century, given a unity of direction unique for its time by a nationwide corps of school inspectors, most of them Protestant ministers, who examined prospective teachers and visited local schools on a regular basis, while receiving guidance and encouragement from the Agent for National Education based in The Hague.

The liberal leadership of the predominant Protestant Church (which, even after it was officially "disestablished" in 1796 continued to play a semi-official role in Dutch life) supported these reforms as contributing to the promotion among the common people of their own religious views. Initially, Catholic leadership supported these educational reforms as an improvement upon the previously preponderant influence of the Protestant church establishment on schools. Thus, the Netherlands-during the first decades of building a system of schooling-avoided the conflict between school policies and the wishes of parents that did so much damage in France at the same period. By the time such conflict broke out, the system was well established.

The public schools were required to teach a "general Christianity" that would develop in their pupils "all social and Christian virtues," as the 1806 law put it. The lawmakers had been "thoroughly convinced of the importance of public education for all classes of society and especially for the upcoming generation, whose happiness hangs above all on the early implanting of the fundamental principles of religion and ethics" (qtd. in Bruin 65). The government decided, in 1817 , to fund some private Jewish schools butin this period-no private Catholic or Protestant schools. Public schools were intended to be 
national, bringing together all children whatever their social background, their (Christian) denomination, or their sex.

Many Protestants who continued to hold to the orthodox Calvinism that had flourished in the sixteenth and seventeenth centuries objected to the liberal, non-doctrinal version of Christianity promoted by the public schools. Although there were daily prayers and Bible reading in the schools, the instruction-especially that concerned with morality-rested upon an anthropology that denied the power of sin and the need for a Redeemer, an approach considered by the orthodox as a denial of essentials of the Christian faith. In protest, some parents kept their children home or sent them to illegal schools; fathers were in some cases sent to jail. In 1834, for example, local authorities in one community ordered the police to issue a warrant against orthodox Protestants who had begun to educate their children in a barn to avoid the objectionable teaching of the public school. The school inspector offered an official opinion that "the founding of a new school is a disruptive movement against the standing order of things" (qtd. in Bos 10), no light charge in that period of social unrest.

There was also resistance from Catholics. This Catholic dissatisfaction took the most dangerous turn in the southern provinces that had formerly been an Austrian possession and had been awarded to the new Kingdom of the Netherlands under the peace concluding the Napoleonic wars. Although the government moved cautiously at first to avoid alarming the heavily Catholic population of Flanders, Brabant, and the other southern provinces, the commission sent to investigate the quality of schooling there concluded that it was out-of-date and ineffective. The measures prescribed by the 1806 law went gradually into effect in the southern provinces, with the establishment of a teacher-training institution and a steady pressure to adopt whole-class instruction and other classroom reforms. School inspectors-the government took care to appoint Catholics-pressed for continual improvements and for teaching on a non-denominational Christian basis (Dodde and Lenders 165ff).

These efforts to impose the model of "general Christianity" on elementary schools and to bring the training of priests within the public system of secondary and higher education aroused growing resistance (Boekholt 140). The government "recognized the principle of educational freedom, but joined to it such control that there was a risk of a state monopoly." The Catholic leadership, in turn, objected to the oversight of schooling by a Protestant king, however lightly that oversight was exercised, and education became one of the issues leading to the successful rebellion of what became Belgium (Wynants 20). The use of schooling as an instrument of nation-building, in this instance, led ironically to the break-up of the nation,

[when] the creation of new generations of young citizens . . . took on the character of patriotic self-affirmation. That was why, when the statesmen at Vienna yoked together northern and southern Netherlands who, for twenty years, had undergone entirely different cultural and administrative experience, the one area where the Dutch had had undisputed success-education-would cause the most bitter contention of the new Kingdom. (Schama 541)

After the loss of the Belgian provinces as a result of such conflicts, the government became more sensitive to the grievances of Catholics in what remained of the Netherlands. In 1822, the Catholic journalist Le Sage ten Broek, a convert from Protestantism, had called on Catholic pastors to start parochial schools, and there were growing complaints that the public schools were too Protestant. Singing religious songs, reading from the Bible, and the lack of crucifixes on school walls were all considered dangerous for the spiritual well-being of Catholic pupils. The efforts of the government, some Catholics charged, were spreading religious indifference through the schools (Bruin 210ff).

Concerned about these growing tensions, especially in view of the Belgian revolt, the government issued a decree in 1842 that responded to many of the concerns of Catholics, though at the price of further alienating orthodox Protestants from the public schools. In filling teacher vacancies, local officials should take into account the religious identity of the local population. All public (and private) schools were required to report on what "books, songs, and writing" they were using so that it could be determined by religious authorities whether any were offensive to 
them; if necessary, offensive passages could be removed. School facilities were to be made available for an hour each day for doctrinal instruction given by the local church, whether Protestant or Catholic (Bruin 241f). The Calvinist Heidelberg Catechism vanished from the public schools in Catholic areas, and books approved by the Catholic hierarchy were introduced. What was to be understood as "general Christian education" was gradually less and less clear, and teachers didn't know how they should approach it (Boekholt 144).

While these measures were greeted with some satisfaction by Catholics, they did not prove a lasting solution for those who wanted explicitly Catholic schooling. While "for the Protestant part of the people the break with the past was too radical, from the Catholic point of view it was not radical enough, since the school retained a Protestant character, was not neutral, and certainly not Catholic" (Boekholt 134).

Protestant intellectual Groen van Prinsterer charged that the public schools were being robbed of their Protestant character, and concluded that the only solution was to allow separate Protestant and Catholic public schools. This proposal was fiercely resisted by those who believed that the common public school was the institution that should knit the nation together.

Over the next decades-some would say for seventy years-one of the dominant issues in Dutch political life was the so-called "school struggle" (schoolstrijd) over, first, the freedom to establish and operate non-state schools with a confessional basis and, second, the right to public funding for these schools. The freedom was already implicit in the 1806 legislation, but the conflicts that had led to the separation of Belgium made it clear that this freedom should be anchored more firmly in fundamental law. The new constitution adopted in 1848, partly in response to the political upheavals in France and elsewhere (Bruin 246), reflected the Liberal desire to reduce the supervision of the state over society, including schooling:

Public education is a matter of continuing concern for the government. The arrangements [inrichting] of public education, with respect for everyone's religious convictions, shall be regulated by law. In all parts of the kingdom public authorities shall provide public elementary education. Providing education is free [that is, anyone may provide education], under the oversight of the authorities and, in addition, with respect to secondary and elementary education, subject to investigation of the qualifications and the moral character of the teachers, both of which are to be regulated by law. (Article 194)

It was not until 1857 , however, that a new education law was passed to replace that of 1806; significantly, the prime mover was an orthodox Protestant who had earlier founded the first private school with a distinctively Protestant character. Public schools should seek to develop in their pupils "all Christian and social virtues" (a reversal of the order of terms from the 1806 law). The 1857 law gave more responsibility to local authorities, who appointed local school committees to oversee the schools. While there were still government inspectors, these came to have a less direct contact with schools (Boekholt 151). An effort to include subsidies for private schools was eliminated during floor debate, and in general the new law was disappointing to supporters of confessional education.

The cost of schools continued to be borne almost entirely by local authorities and by parents until 1878. A new generation of Liberals, more committed to government intervention and less to parental freedom and explicitly hostile to confessional schools (Langedijk 140), enacted education legislation providing that the state would pay thirty percent of the cost of schools and, under some circumstances, even more. Other provisions of this law increased significantly the costs of schools. The legislation was opposed by supporters of confessional education since it would make their schools much more expensive to operate. Confessional schools would remain free, Protestant leader Abraham Kuyper noted, "yes, free to hurry on crutches after the neutral [school] train that storms along the rails of the law, drawn by the golden locomotive of the State" (Gilhuis 152).

The Liberals had overreached. This threat against the schools that many of the orthodox common people had labored to establish aroused them and created a movement that, in a decade, reversed the political fortunes of the Liberals and brought state support for confessional schools. A 
massive petition drive collected, in five days, 305,102 signatures from Protestants and 164,000 from Catholics asking the king to refuse to sign the new legislation. When that failed, a national organization, "The Union 'A School With the Bible," " created a permanent mechanism for the mobilization of orthodox Protestants, which soon led to the establishment of the first real political party in the Netherlands, significantly called the Anti-Revolutionary Party.

Catholics were equally active, and together with the orthodox Protestants, they gained a majority in Parliament by 1888 . As an historian of Dutch liberalism has pointed out, the effort to smother the last flickering flame of orthodox religion only succeeded in fanning it into vigorous life (Riel 108, 111).

The School Law of 1889 provided the same 30 percent state subsidy to confessional schools as to local government schools and began a process that would lead, in 1920, to the full financial equality of all schools meeting the quality requirements set by the state. The 1889 law also forbade local authorities from making their schools free, a strategy that many had employed to compete with private confessional schools (Boekholt 219). The intention was to create a more level playing-field, though it would require another thirty years of political struggle to establish the present Dutch system, under which there is no financial incentive to send one's children to a secular public school rather than to a religious school and under which about 70 percent of all pupils attend non-public schools, most of them Catholic or Protestant.

The "politics of accommodation" (Lijphart's phrase) allowed - and continues to allow-policy issues involving religious institutions and the religious convictions of what is now a minority of the population to be resolved without the bitter conflict that resonates in France.

\section{England}

The development of popular schooling in England (in contrast with Scotland) was almost entirely the result of private initiatives. In 1833, in the immediate wake of the widening of the electoral franchise through the Reform Act of 1832, Lord Brougham called for "the improvement of the moral condition of the people by affording them the means of popular education," through support for the voluntary bodies set up by members of the Church of England, on the one hand, and by "Dissenters," on the other (Simon 164). Such measures were opposed by the Irish leader in Parliament, Daniel O'Connell, who argued that "nothing could be more destructive than to imitate the example of France in respect to her system of national education" (qtd. in Green 263). While the initial measures were defeated, the issue did lead to a compromise under which a grant of $£ 20,000$ was distributed equally to the two English denominational societies (and another $£ 10,000$ to the Church of Scotland the following year) for construction of schools. The terms of the act are significant: the funds were "to be issued in aid of private subscriptions for the erection of school houses for the education of the poorer classes of Great Britain" (qtd. in Reisner 249).

After decades of heroic efforts by denominational groups, with partial public subsidies, to extend popular schooling - especially in the rapidly-growing cities-Parliament passed the 1870 Education Act, which served as the charter of a system of publicly-controlled schooling. The purpose of this bill was not to replace the denominational schools or private initiatives, but to ensure that all children had access to adequate schools:

Our object is to complete the present voluntary system, to fill up gaps, sparing the public money where it can be done without, procuring as much as we can the assistance of the parents, and welcoming as much as we rightly can the co-operation and aid of those benevolent men who desire to assist their neighbours. (qtd. in Maclure 100)

The 1870 Act was built upon three essential compromises among denominational and other groups: a conscience clause to excuse pupils from religious instruction, non-denominational inspection of schools, and "compliance with conditions securing secular efficiency." The Act had widespread effects:

[It] upset the Anglicans for establishing School Boards, authorized to set up non-sectarian schools supported from local taxation. It upset Nonconformists and Secularists by stating that these Board Schools would supplement, rather than replace, the denominational schools, and that 
denominational schools would continue to receive state grants. It upset Secularists and some Nonconformists by permitting the new schools to provide religious teaching, provided they did not teach the formularies of any specific denomination. At the same time it defused criticism slightly by introducing a 'Conscience Clause' permitting parents to withdraw their children from religious instruction. (McLeod 72)

Everyone was upset, but everyone could live with the results. A period of six months was granted to the churches to propose additional schools, before local boards would be formed to address the unmet needs. The Church of England immediately unveiled plans for an additional 2,900 schools, while other denominations proposed an additional 400 .

Unlike France in the same period, England did not consider it necessary that schools become secular as well as free and compulsory. Religion remained-as it is to this day in England-a regular part of the curriculum in most public schools, though the 1870 Act required that it be undenominational. Protestant Dissenters as well as free-thinkers had long argued that "in national education all differences of opinion in religion and politics should be laid aside; we should endeavour to fortify the mind against prejudices and error by inculcating principles of universal truth" (Quarterly Journal of Education [1835], qtd. in Dyson \& Lovelock 92).

A few school boards, notably that of the Liberal stronghold Birmingham, decided that the instruction in their schools would be strictly without religious elements, but this decision was overturned in 1879 and thereafter the schools included Bible reading-without commentary-in the daily program. Manchester, by contrast, provided fifty minutes a day of Christian religious instruction in its public schools (McLeod, 72). Before World War II, public schools often used the "agreed syllabus" developed by an ecumenical group of Protestants in 1924 (Timmins 81).

The role of the church-sponsored schools was further strengthened by the 1902 Education Act, which entitled them to local tax support as well as the central government grants that they were already receiving. In urging its enactment, Prime Minister Balfour pointed out that it would redress "the deplorable starvation of voluntary schools," which after all were serving the majority of schoolchildren. "As we have . . . left to the parents the responsibility for choosing what religion their children are to learn, surely we ought . . . to make our system as elastic as we can in order to meet their wishes" (qtd. in Maclure 151ff). The Act created some 300 local education authorities (LEAs), superseding local school boards in the control of what would henceforth be called "provided" schools and exercising substantial authority, as well, over the secular education provided in publicly-subsidized "non-provided" denominational schools. The LEAs assumed much of the funding and oversight responsibility previously exercised by national authorities (Phillips 117-172), in exchange for a third of the seats on the governing boards of these voluntary schools. Local taxes were to be provided on an equal basis to the two categories of schools, supplemented in both cases by national grants.

Arrangements for denominational schooling were codified in the Education Act 1944, under which

the financial settlement was made more generous to the voluntary bodies. Church schools could choose "Aided" or "Controlled" status. "Aided" schools were to receive grants to cover teachers' salaries and other maintenance charges; a grant of 50 percent toward the cost of alteration of buildings; the cost of all internal repairs and half the cost of external repairs. Other grants at 50 per cent (increased to 75 per cent in 1959) were payable in respect of new school building when a school was transferred to a new site because the existing premises could not be brought up to standard, or where a new school was to be built in substitution for one or more existing schools. . . . In Aided schools, the appointment of staff remained in the control of the Governors or Managers, the majority of whom were to be nominated by the Voluntary [denominational] body. As for Controlled schools, their governing bodies were to include a majority of L.E.A. representatives but denominational instruction was permitted to continue. Their schools became the financial responsibility of the L.E.A. (Maclure 222)

As R. A. Butler, its primary creator, intended, the 1944 Act "settled, apparently once and for all, the religious question" (Timmins 92). While Roman Catholic schools (9.8 percent of all 
government-supported schools) chose the more independent "aided" status, the majority of the Church of England schools that make up 21.3 percent of government-supported schools are "controlled" (12.5 percent vs. 8.8 percent "aided"). Much depends, for "voluntary controlled" schools, upon whether the representatives of the local education authority are willing to support the denominational character of the school in curriculum and other decisions (Chadwick 62).

\section{The United States}

The 1830s in the United States, as in Western Europe, was a decade of intense interest in popular schooling. Dispersal of the native population beyond the reach of the civilizing institutions of the East was one of the pressing concerns of this reform movement; another was the growing number of immigrants. A group of educators in Ohio expressed, in 1836, their concern with the "vast tide of immigration, yearly flowing in upon us, from all nations." The only answer was "to take their children ... and educate them in the same schools with our own, and thus amalgamate them with our community" (qtd. in Cohen II, 991). Nor was this concern limited to the West; the president of Middlebury College in Vermont asked, in 1849, "shall these adopted citizens become a part of the body politic, and firm supporters of liberal institutions, or will they prove to our republic what the Goths and Huns were to the Roman Empire? The answer to this question depends in a great degree upon the wisdom and fidelity of our teachers and associated influences" (qtd. in Cohen Vol. II, 995).

When Catholic immigrants (Germans first, then other groups) began to organize their own schools, this development was perceived by many as an expression of a refusal to accept the requirements of life in American society. "They will be shut up," warned a prominent Protestant minister in 1853 , "in schools that do not teach them what, as Americans, they most of all need to know ...." If, instead, the children of immigrants could be gathered into the common public school, "we may be gradually melted into one homogeneous people" (Bushnell 299-303).

Catholic schools, influential Americans believed, were a menace to society, and their reli- gious justification was in fact no justification at all. In such schools, the children of immigrants "will be instructed mainly into the foreign prejudices and superstitions of their fathers, and the state, which proposes to be clear of all sectarian affinities in religion, will pay the bills!" Bushnell found it "a dark and rather mysterious providence, that we have thrown upon us, to be [sic] our fellow-citizens, such multitudes of people, depressed, for the most part, in character, instigated by prejudices so intense against our religion" (Bushnell 299).

One of the most influential of the education reformers, Ellwood Cubberley, proclaimed in 1909 that "each year the child is coming to belong more to the state, and less and less to the parent." $\mathrm{He}$ and his allies were confident that "[s]ociety would control its own evolution through schooling [;]. . . science would replace religion and custom as sources of authority" (qtd. in Tyack and Hansot 106, 103, 107).

What accounts for the change from public schools permeated with broadly Christian themes and practices only forty years ago to the exclusion of Christmas trees and Santa Clauses from many today? A quick answer might be that American society has become more respectful of cultural diversity, and that the exclusive presence of Christianity would no longer be considered acceptable. While true, this explanation is not adequate. It is routine in other Western democracies to give equal, or at least proportional, time to different religious traditions as they are represented in a particular school. Wouldn't that be the appropriate multicultural thing to do? But few American public schools do so; their presentation of cultural diversity rarely includes religious themes in a serious way.

As with most social phenomena, there is no single explanation for the exclusion of living religions from American public schools. It would be easy to assume that it is an inevitable consequence of modernity and of a growing societal pluralism, leading to the secularization of public life. Public schools would, by this account, simply be following wider social trends. However, this explanation doesn't work. In the first place, the American people are not growing more indifferent to religion than they were in the past, nor are they as secularized as the peoples of Western 
Europe, where religion continues to play a much more prominent part in public education. In the second place, the public schools are not following a trend in public life but leading it. Religion receives much more public recognition and support in Congress, in the military, in governmentfunded social and health services, in prisons, and in higher education than it does in American public schools (Glenn 2000). The schools are an island of secularity in a sea of varied but frequently dynamic religious expressions.

How do we explain the anomaly, then, that schools, which we would expect to be more intimately concerned with communicating an account of the nature of the Good than any other sphere of public life, are, in fact, the most rigorously purged of any such themes?

Among the contributing factors to this development is a way of thinking about education and religion that was originally held by a relatively small elite who saw universal schooling as a means of transforming society by "popular enlightenment," particularly in the face of what was perceived as a deeply threatening immigration of Catholics from Ireland and Germany, and then from Poland, Italy, and elsewhere. This flood of aliens, mostly concentrated in a highlyvisible way in America's cities, seemed to threaten to transform everything that old-stock Americans held most dear. Fear of what Germans call Überfremdun, an excess of foreigners, not unlike what many French people are feeling today, led to an emphasis upon the assimilating role of the public school. This fear, in turn, required that whatever might prevent immigrant parents from enrolling their children must be eliminated; I have told this story in some detail in The Myth of the Common School.

The assumption that public schools should avoid anything that could prove controversial can be traced back to Horace Mann, who was concerned that schools not discuss the abolition of slavery or what he called the "horrible doctrines" of sin and redemption, and it has continued to be widely accepted by teachers as a result of the norms absorbed during their professional training. It is possible to trace the expanding influence of this ideology over the course of the nineteenth and twentieth centuries, and to interpret some of the recent developments in American education as reactions by the broader public against this now-dominant set of assumptions within the rather closed world of public education.

Perhaps the most available evidence is found through study of changes that have occurred in commonly used school textbooks. Oppewal, in 1972, studied "two junior high literature anthologies published by the same company twenty-five years apart [and found] that the editors had, perhaps unconsciously, reduced significantly the number of references to theistic thought and practice in the characters in stories, and in poems and essays. . . [;] in the forties there were three times as many lines devoted to theistic expression as in the sixties." Another study, by George Hillocks of the University of Chicago, looked at the curriculum in Kanawha County, West Virginia, the site of a widely reported confrontation between religiously conservative parents and the public schools in the early seventies, and found that "only six of the thirty-eight prose selections mentioned Christians or Christian beliefs explicitly. In addition, he noted that all six of the prose selections were 'pejorative' of Christianity, either directly in adverse comments about the shortcomings of Christianity or indirectly by showing Christians as hypocrites or fools" (McCarthy et al 21f).

What is still the best study of this phenomenon was published twenty years ago by Paul Vitz, a New York University professor of psychology, based upon research he had carried out for the National Institute of Education. Vitz studied commonly used elementary-school social studies textbooks, high school U. S. history textbooks, and basal readers, using a careful method of scoring the content of words and pictures. He concluded that, though to a varying extent, all of these texts were biased. "The nature of the bias," he wrote, "is clear. Religion, traditional family values, and conservative political and economic positions have been reliably excluded from children's textbooks." For example, none of the sixty social-studies texts that he studied "contain one word referring to any religious activity in contemporary American life." There was "an occasional rare picture (without captions) in these sixty books [that] does depict Jewish, Amish, or vague nondenominational religious scenes. The 
few pictures, all told there were only eleven, that do refer to religious activity were distributed over sixty books and roughly 15,000 pages." The censorship went to comical extremes: "One social studies book has thirty pages on the Pilgrims, including the first Thanksgiving. But there is not one word (or image) that referred to religion as even a part of the Pilgrims' life." Similarly, almost the only oblique reference to religion that he found was in a description of a Latino neighborhood: "Churches have places for dances and sports events" (Vitz 3, 11).

In the eight high school U. S. history texts that he analyzed, Vitz found a similarly unbalanced treatment of religion: "There is not one book that recognizes the continuity of the revival and evangelical movements throughout American history since the Colonial Period. . . . Prejudice against Catholics is commonly noted, but positive contributions in terms of the assimilation of countless immigrants, the many hospitals and orphanages built by Catholics, and the significance of the Catholic school system are (with one exception) not mentioned" (Vitz 57).

Vitz also examined twenty-two basal readers for third and sixth grades, and he found that "there is not one story or article in all these books, in approximately nine to ten thousand pages, in which the central motivation or major content derives from Christianity or Judaism. . . . There are scores of articles about animals, archaeology, fossils, or about magic_-but none on religion" (Vitz 65).

\section{Conclusions}

It is evident that the quite different historical experiences of this sample of countries go a long way toward explaining how religion is treated in the public schools of each.

That there could be a controversy in Germany about crucifixes on the walls of public school classrooms-unthinkable in the United Statesreflects the repeated decisions, in the nineteenth century and again under Weimar and again after World War II, to maintain the confessional character of public schools and to provide confessional religious instruction in those schools. Originally based upon the conviction of policymakers that the religious instruction of the common people, in the interest of morality and social stability, was the most important function of public schooling, the presence of religion in schools was later also justified as a way to prevent development of alternative schools outside the public system and thus to strengthen the role of public schools as an instrument of nation-building. This motivation was, in turn, supplemented, if not altogether replaced, in the 1920s and again in the 1950 s by a concern for liberty of conscience and the rights of parents.

In the Netherlands, by contrast, religious controversy has largely been avoided by allowing different groups-including Muslims and Hindus - to have their own publicly-funded schools, while requiring that these schools comply with rather detailed government requirements.

The continuing role of religion in public schools in England-though (as in Germany) weakened by secularization and the demands of an ever-expanding curriculum-came about in a rather different way that continues to have its effects. In England it was private ("voluntary") associations based upon Protestant denominations that took the initiatives to establish, staff, and maintain thousands of schools, with financial support but limited supervision by government. These schools, and the Catholic schools that were established at an increasing rate later in the nineteenth century, had an unapologetically religious character. When, after 1870, municipal and country public authorities entered into competition with the voluntary schools, the initiative still remained profoundly local, and it has only been within the last two decades that the national government has become deeply involved in setting standards for schools. This tradition of local initiative has carried over into the provision of religious instruction and the required religious observances in schools. Negotiation of agreed syllabi occurs among representatives of the various religious groups locally, and schools have considerable discretion to take into account the religious identities of the families that they serve in deciding how religion will be discussed and practiced.

France and the United States are the two countries among our sample and among Western nations that are most resolute about keeping religion out of public schools, though for quite different reasons. In the case of France, there was a 
long history of conflict between the enormous social power of the Catholic Church, which was resurgent throughout the nineteenth century, and a political and cultural class that we can loosely define as "free thinking" and that also increased its power as the country urbanized. For reasons that are historically and sociologically complex, the latter remained in power throughout the Third Republic, and Catholics did not (as in several other countries at the time) form their own political party to advance their interests. The control of the political process by the secular elite was never altogether secure, however, and this control made it seem all the more urgent to use public schools as the primary instrument of creating loyalty to the secular republic. A striking aspect of the significance attached to secularity in France is that it came to mean far more than a simple neutrality among competing worldviews, much less an exclusion of all such perspectives from the public school and from public life in general. Laïcité has taken on something of the function of an alternative belief-system.

In the United States, by contrast, the legal exclusion of religion from public schools has evolved over the last half-century, as a result of a series of decisions by the federal courts, decisions that in most cases were strongly condemned by public opinion and often by elected officials, who saw their own efforts to accommodate religious diversity in the schools overturned on the basis of what seemed abstract legal principles. While an ideological commitment to secularity, on the French model, is by no means absent among American elites, it is not as deeply rooted as it is in France. The fact that the sessions of the Supreme Court are opened with an invocation of God, that the sessions of the Congress are opened with prayer, that the President takes his oath of office on a Bible, and that there are countless other public manifestations of at least a residual piety makes it all the more extraordinary that religion is scarcely, if ever, mentioned in most American public schools, even in the study of history and other subjects where it could be expected to receive extensive consideration.

Although the legal rulings of recent decades are the most obvious cause of this secularization of American public schools, its causes, in fact, reach back a hundred years earlier, in the response to the massive immigration of Catholics from Ireland and Germany. It was in the hope of persuading immigrants to send their children to public schools where they could be made into "real Americans" that school officials in northern cities—usually without much discussion—gradually removed any elements of instruction or school life that reflected the Protestant past of the educational system. This course was just the opposite of the course followed by German education officials in their successful efforts to keep Catholic children in public schools and, unlike Germany, America found that the effort was largely a failure. Making public schools religiously void did indeed remove a Catholic objection, but it did not satisfy the desire of Catholic parents for schooling that reflected their convictions. By 1950, there were three million pupils attending private Catholic schools and many hundreds of thousands attending the schools established by Protestant immigrant groups.

The secular character of American public schools has become so deeply rooted that nothing seems likely to change it, which explains the continuing growth of private school alternatives as well as the extraordinary phenomenon of "home schooling." To the extent that educational vouchers continue to gain both popular support and legal legitimacy, it seems likely that religious expression and even study about religion will continue to be a characteristic of most private but few public schools.

This brief historical survey-and it could be usefully extended to other countries, such as Austria, where conflict over public schooling between Catholics and Socialists dominated the political scene in the 1920s and made progress difficult-suggests that conflict over religion in public schools is less likely to be an issue when alternative schools expressing a distinctive worldview are made widely available, either within the public system, as in England and Ontario, or through public funding of private religious schools, as in the Netherlands, Belgium, Australia, and other Western democracies. Such a policy would greatly reduce such conflict in the United States.

Even such funding of alternative schools is not sufficient, as the example of France demonstrates, if the public school comes to be symboli- 
cally and uniformly identified with a particular worldview-in this case with a denial of the significance of religion, for believers, in all spheres of life and identity. French and American policymakers might usefully reflect whether a free society should not so structure its educational system that religious conviction-the dimension of culture that, for many citizens, matters most profoundly-can find an honored place.

\section{Works Cited}

Avenarius, Hermann \& Hans Heckel. Schulrechtskunde $7^{\text {th }}$ edition. Kriftel: Luchterhand, 2000.

Barbier, Maurice. LaLaïcité. Paris: Editions L'Harmattan, 1995.

Baubérot, Jean. Vers un Nouveau Pacte Laïque? Paris: Éditions du Seuil, 1990.

—. La Morale Laïque contre l'Ordre Moral. Paris: Éditions du Seuil, 1997.

Blais, Marie-Claude. Au Principe de la République: Le Cas Renouvier. Paris: Gallimard, 2000.

Boekholt, P. Th. F. M. "Eenheid en verscheidenheid in het onderwijs, 1795-1860." Geschiedenis van de School in Nederland. Eds. Boekhold and De Booy. Assen/Maastricht: Van Gorcum, 1987.

Bruin, A. A. van. Het Onstaan van de Schoolstrijd. Barneveld: Ton Bolland, 1985.

Bushnell, Horace. Life and Letters. New York: Harper, 1880.

Chadwick, Priscilla. Shifting Alliances: Church and State in English Education. London: Cassell, 1997.

Chevallier, Pierre. Histoire de la Franc-Maçonnerie Française, Vol. 2. La Maçonnerie: Missionnaire du Liberalisme (1800-1877). Paris: Fayard, 1974.

Cohen, Sol. Education in the United States: A
Documentary History, Vol. I - V. New York: Random House, 1974.

Curtis, Sarah A. Educating the Faithful: Religion, Schooling, and Society in Nineteenth-Century France. Dekalb: Northern Illinois UP, 2000.

Déloye, Yves. École et Citoyenneté. Paris: Presses de la fondation nationale des sciences politiques, 1994.

Dodde, Nan L., and Jan H. G. Lenders. "Reform, Reorganisation und Stagnation: Der Schulunterricht in den Niederlanden und Belgien 1750-1825." Revolution des Wissens? Europa und seine Schulen im Zeitalter der Aufklärung (1750-1825). Eds. Wolfgang Schmale and Nan L. Dodde. Bochum, Germany: Verlag Dr. Dieter Winkler, 1991.

Durand-Prinborgne, Claude. Le Droit de l'éducation. Paris: Hachette, 1998.

Dyson, A. E. and Julian Lovelock. "Introduction." Education and Democracy. London: Routledge 1975.

Gaspard, Françoise and Farhad Khosrokhavar. Le Foulard et la République. Paris: Éditions La Découverte, 1995.

Gilhuis, T. M. Memorietafel van het Christelijk Onderwijs: De Geschiedenis van de Schoolstrijd. Second edition. Kampen: Kok, 1975.

Glenn, Charles L. The Myth of the Common School. Amherst: U of Massachusetts P, 1988.

-. "Hijab and the Limits of Tolerance." In The Legal Status of Minorities in Education. Ed. Jan De Groof and Jan Fiers. Leuven, Belgium: Acco, 1996.

- The Ambiguous Embrace: Government and Faith-Based Schools and Social Agencie. Princeton: Princeton UP, 2000.

-- and Jan De Groof. Finding the Right Balance: Freedom, Autonomy, and 
Accountability in Education. Vol. I and II. Utrecht: Lemma, 2002.

Green, Andy. Education and State Formation. London: Macmillan, 1990.

Lalouette, Jacqueline. La Libre Pensée en France. Paris: Albin Michel, 1997.

Lamberti, Marjorie. State, Society, and the Elementary School in Imperial Germany. New York: Oxford UP, 1989.

Maclure, J. Stuart. Educational Documents: England and Wales 1816 to the Present Day. Fifth edition. London: Methuen, 1986.

McCarthy, Rockne, Donald Oppewal, Walfred Peterson, and Gordon Spykman. Society, State, and Schools. Grand Rapids: Eerdmans, 1981.

McLeod, Hugh. Secularization in Western Europe, 1848-1914. New York: St. Martin's, 2000 .

Nicolet, Claude. L'Idée Républicaine en France (1789-1924). Paris: Gallimard, 1982.

-. "Jules Ferry et la Tradition Positiviste." Jules Ferry: Fondateur de la République. Ed. François Furet. Paris: École des Hautes Études en Sciences Sociales, 1985.

Ozouf, Jacques and Mona Ozouf. La République des Instituteurs. Paris: Gallimard, 1992.

Ozouf, Mona. L'École, l'Église et la République, 1871-1914. Paris: Cana, 1982.

Phillips, Francis R. Creating an Education System for England and Wales. Lewiston, NY: Edwin Mellen Press, 1992.

Ponteil, Félix. Histoire de l'Enseignement en France, 1789-1965. Paris: Sirey, 1966.

Rebérioux, Madeleine. La République Radicale? 1898-1914. Paris: Éditions du Seuil, 1975.

Reble, Albert. Geschichte der Pädagogik. $20^{\text {th }}$ edition. Stuttgart: Klett-Cotta, 2002.

- - Geschichte der Pädagogik: Dokumentationsband. $4^{\text {th }}$ edition. Stuttgart: Klett-Cotta, 1999.

Reisner, Edward H. Nationalism and Education since 1789. New York: Macmillan, 1922.

Rémond, René. L'Anticléricalisme en France. Paris: Éditions Complexe, 1985.

Schama, Simon. Patriots and Liberators: Revolution in the Netherlands 1780-1813. New York: Knopf, 1977.

Simon, Brian. The Two Nations and the Educational Structure 1780-1870. London: Lawrence \& Wishart, 1960.

Tent, James F. Mission on the Rhine: Reeducation and Denazification in AmericanOccupied Germany. Chicago: U of Chicago P, 1982.

Thiel, Markus. Der Erziehungsauftrag des Staates in der Schule: Grundlagen und Grenzen staatlicher Erziehungstätigkeit im öffentlichen Schulwesen. Berlin: Duncker and Humblot, 2000.

Tyack, David and Elisabeth Hansot. Managers of Virtue: Public School Leadership in America, 1820-1980. New York: Basic, 1982.

van Riel, Harm. Geschiedenis van het Nederlandse Liberalisme in de 19e Eeuw. Assen: Van Gorcum, 1982.

Visse, Jean-Paul. La Question Scolaire 1975-1984. Paris: Septentrion, 1995.

Vitz, Paul C. Censorship: Evidence of Bias in Our Children's Textbooks. Ann Arbor: Servant Books, 1986.

Waterkamp, Dietmar. "Erziehung in der Schule." Vergleich von Bildung und Erziehung in der Bundesrepublik Deutschland und in der Deutschen Demokratischen Republik. Eds. Oskar 
Anweiler et al. Köln: Verlag Wissenschaft und Politik, 1990.

Zeldin, Theodore. Politics and Anger. Oxford UP, 1979.

Zielbauer, Paul. "Judge Rules School District Erred on Religion in Classroom." New York Times 22 May 1999. 